\title{
SOKOLOWIA HORIZON OF THE ZIARAT FORMATION (EASTERN ALBORZ, IRAN): BIOSTRATIGRAPHIC AND PALEOGEOGRAPHIC IMPLICATIONS
}

\author{
Mehdi Hadi ${ }^{1}$, Amir Salahi ${ }^{1}$, Yaghub Nasiri ${ }^{1,2}$ \& Hossein Mosaddegh ${ }^{3 *}$
}

Received: 23 December 2018 / Accepted: 09 July 2019 / Published online: 14 July 2019

\begin{abstract}
The present study deals with molluscan accumulations of the Sokolowia horizon, which is a key-bed in the middle Eocene of the Kalateh section (Ziarat Formation, Eastern Alborz, Iran). The age of this "key horizon" is attributed to Bartonian based on presence of larger benthic foraminifera species such as Nummulites lyelli (D'Archiac \& Haime), Orbitoclypeus zitteli (Checchia-Rispoli) and Asterocyclina stella stella (Gümbel) immediately below it. The paleogeographic distribution of Sokolowia occurrence from Tarim Basin in eastern Central Asia to the Transylvanian Basin in southeastern Europe indicates a middle Eocene seaway along the southern margin of an Eurasian epicontinental sea. In particular, the comparison of middle Paleogene sequences in different Central Asian regions reveals an apparent similarity between those basins pointing to their genetic relationship.
\end{abstract}

Keywords: Sokolowia; larger benthic foraminifera; Central Asia; Eastern Alborz

\section{INTRODUCTION}

During the Paleogene (65 to $23 \mathrm{Ma}$ ) the Earth experienced paleoclimatical and paleobiological variations, such as numerous extinction events, extreme temperature fluctuations, and changes in the diversity and frequency of different species (Thomas, 2003; Zachos et al., 2003; Gradstein et al., 2004). Among the various groups of organisms, oyster bivalves are the most abundant macrofossils in the Cenozoic shallow water sediments of Central Asian basins (see Berizzi Quarto di Palo, 1970; Lan, 1997; Bosboom et al., 2011). Despite not as diverse as other bivalve groups, oysters include some excellent index species with short time ranges between evolutionary appearance and extinction, being therefore very useful biostratigraphic tools in shallow marine settings (Griffin et al., 2005; Bosboom et al., 2015). Besides, many authors consider oysters for important proxies for paleoenvironmental conditions in epicontinental basins, however, only few studies have been conducted throughout the Tethys area over the Eocene time (Lan, 1997; Rusu et al., 2004; Griffin et al., 2005; Bosboom et al., 2011). The main objective of the present study is to establish a biostratigraphic correlation of the Sokolowia horizon from the Kalateh section (Ziarat Formation, Eastern Alborz) with the Central Asian basins to the East and the Transylvanian Basin to the West. In order to determine the age of the "Sokolowia horizon" in the studied section, biostratigraphic examination of larger benthic foraminifera was conducted in an earlier study (Hadi et al. 2019). That new data, contribute significantly to a more precise reconstruction of the paleo-sea way across the proto-Paratethys between the eastern parts of Central Asia (Tarim, Ferghana and Afghan-Tajik basins) and the Southeastern Europe (Transylvanian Basin) during the middle to late Eocene.

\section{GEOLOGICAL SETTING AND STRATIGRAPHY}

Being a part of the largest mountain belt of the AlpineHimalayan system the Iranian plateau has been subdivided into eight sedimentary-structural provinces characterized by different tectonic and sedimentary events (Stöcklin, 1968; Aghanabati, 2004), (Fig. 1a): (1) Alborz, (2) Central Iran, (3) Zagros, (4) Kopet-Dagh, (5) Lut, (6) Sanandaj-Sirjan, (7) Urumieh- Dokhtar (Sahand-Bazman) magmatic arc, and (8) Makran (Fig. 1b). In northern Iran the Alborz range (about $600 \mathrm{~km}$ long and $100 \mathrm{~km}$ wide) is one of the most investigated geological-structural zones. The E-W trending Alborz mountains belt as one of the most tectonically active zone in the AlpineHimalayan orogenic belt is located between the Caspian Sea Basin to the north and the Central Iran Basin to the south. The Alborz range spreads westward into the Pontides Arc (in easternmost Turkey) and the Lesser Caucasus (in Georgia and Armenia) (Asiabanha \& Foden, 2012).

The Alborz region is a tectonically active zone formed due to the collision between the Gondwana and the Eurasian plate after the closure of Paleo-Tethys Ocean in the Permo-Triassic time (Sengör \& Burker, 1978; Stampfli et al., 1991). Following the northward subduction of the Palaeo-Tethys, the Alborz margin, divided into western, central, and eastern sector, was affected by the Cimmerian and Alpine orogenic phases (Alavi, 1996).

Generally, in the southern Alborz flank three lithostratigraphic formations are distinguished (Dellenbach, 1964; Stöcklin, 1972): (1) the Fajan Formation (Paleocene-early Eocene) is mainly composed of continental, terrestrial shales, red conglomerates and sandstones, (2) the Ziarat Formation (early-middle Eocene) mainly comprises foraminiferal limestones, sandy limestones, silty and calcareous marls, and (3) the Karaj Formation (middle Eocene) characterized a more than $3000 \mathrm{~m}$-thick succession of shale, sandstone, tuffaceous sandstone and gypsum. 


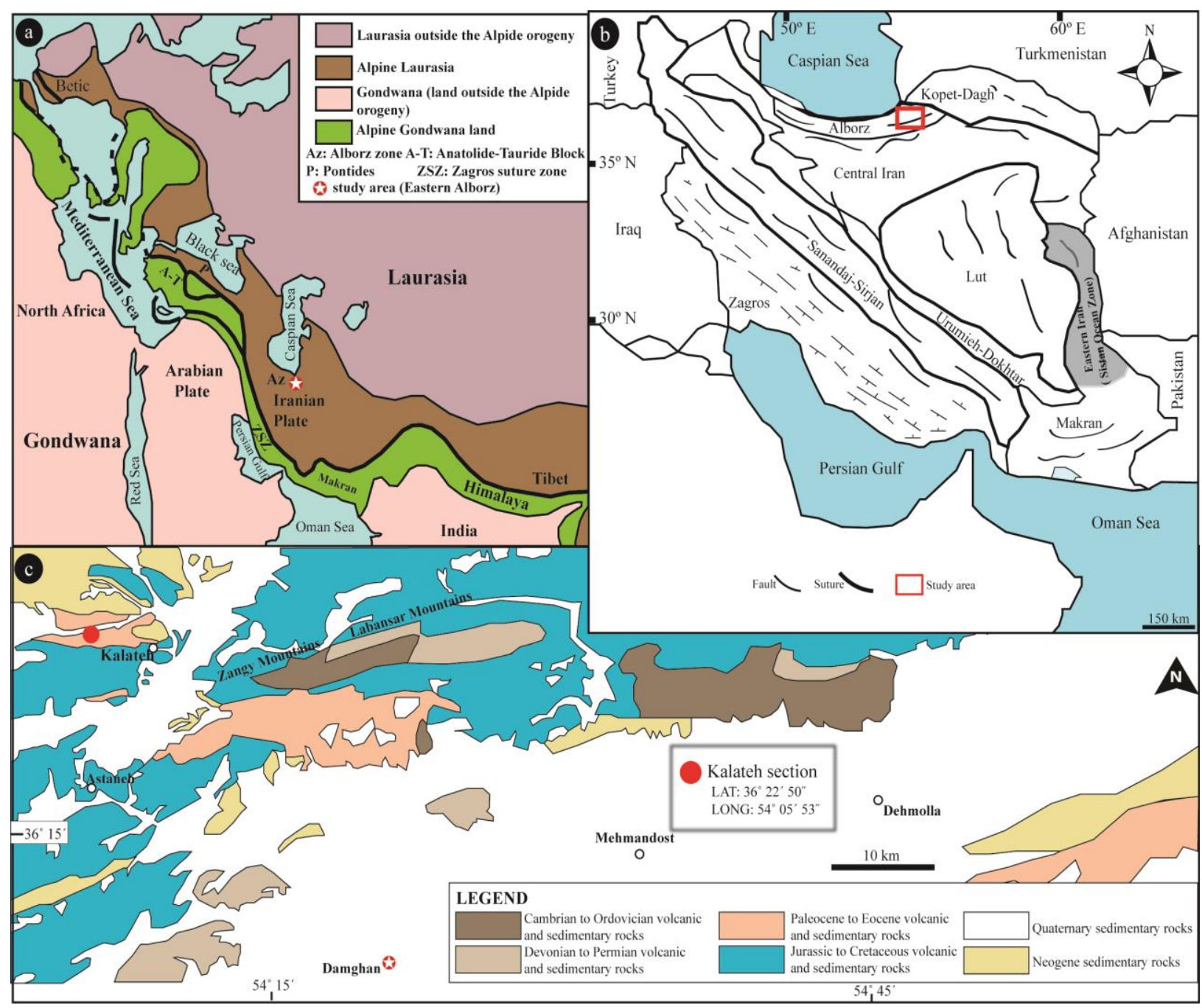

Fig. 1 a Tethys mountain ranges (simplified from Okay, 1989 and Özcan et al., 2015) and location of studied region in eastern Alborz zone. b Modified sketch map of Iran showing geologic provinces (adapted from Stöcklin, 1968 and Aghanabati, 2004). c Simplified geological map from eastern Alborz region (after General geological map of Iran, 1:250000 from Sharabi, 1990). Modified after Hadi et al. (2019).

The Sokolowia shell accumulations have been studied in the Kalateh section, which belongs to the Ziarat Formation (middle Eocene). The section is located $5 \mathrm{~km}$ northwest of Kalateh village and $40 \mathrm{~km}$ northwest of Damghan city. It is situated in the Gorgan $1 / 250000$ quadrangle (sheet-7855; after Sharabi, 1990) (coordinates: $36^{\circ} 22^{\prime} 50^{\prime \prime} \mathrm{N}$; 59 $29^{\circ}$ 54" E) (Fig. 1c). The first note on the shallow marine deposits of the Kalateh section and its mollusk fauna was provided by Grewingk (1853), citing its position as valley to Surt (=Orost) near Namakeh (village $\mathrm{N}$ of Kalateh). From material collected there by botanist Fedor A. Buhse he erected the new species termed Gryphea buhsei (=Sokolowia buhsii). The Kalateh section (Fig. 2) consists of $25 \mathrm{~m}$ thick nummulitic and coralline red algal limestone, which is superposed by a $7 \mathrm{~m}$ thick interval of silty marl and marly limestone intercalated by Sokolowia accumulations. The lower boundary of Sokolowia marly limestone is sharp and erosional with nummulitic and coralline red algal limestone. The lower part of the Sokolowia accumulation is characterized by articulated and low fragmentation shells in silty mudstone matrix. The upper part is characterized by disarticulated, convex-up, highly fragmented and poorly sorted large Sokolowia with normal grading, sharp and erosional base in the uppermost part. Here, we have three types of shell concentrations with thickness, including (1) 40-60 cm, (2) $\sim 1.5 \mathrm{~m}$, and (3) $0.5-1 \mathrm{~m}$. Larger benthic foraminifera from the topmost part of the lower unit, about $1.5 \mathrm{~m}$ below the lowermost Sokolowia accumulation (Fig. 2) indicate biostratigraphic correlation with the zones SBZ17-SBZ18b suggesting the Bartonian age (Hadi et al. 2019).

\section{MATERIALS AND METHODS}

Oyster bivalves pertaining to the Ziarat Formation of the Kalateh section were collected with well-preserved for systematic descriptions from silty marl and marly limestone deposits. Thirty specimens for oysters were investigated and photographed by a Cannon 60D camera and macro lens L100. Also, the identification of the genus and species are mainly based on taxonomic descriptions given by Berizzi Quarto di Palo (1970), Stenzel (1971), Lan \& Wei (1995). The material is housed in the collection at Ferdowsi University of Mashhad by M. Hadi. 
Table 1 Simplified lithostratigraphic description of the Kalateh section in the eastern Alborz basin from the Paleogene deposits correlated with the Kopet-Dagh-Alborz basins which are summarized from Dellenbach (1964), Stöcklin (1972), Afshar-Harb (1994) and Rezaeian (2008).

\begin{tabular}{|c|c|c|c|c|c|c|c|c|}
\hline \multicolumn{3}{|c|}{ Kopet-Dagh basin } & \multicolumn{3}{|l|}{ Alborz Basin } & \multicolumn{3}{|c|}{ present study (eastern Alborz basin) } \\
\hline Age & Formation & Lithology & Age & Formation & Lithology & Age & Formation & Lithology \\
\hline $\begin{array}{l}\text { early Eo- } \\
\text { cene-early } \\
\text { Oligocene }\end{array}$ & Khangiran & $\begin{array}{l}\text { sandstone, } \\
\text { silty marl and } \\
\text { marl, bivalves } \\
\text { (oysters) }\end{array}$ & $\begin{array}{l}\text { Middle } \\
\text { Eocene }\end{array}$ & Karaj & $\begin{array}{l}\text { black shale, } \\
\text { green tuff with } \\
\text { intercalation of } \\
\text { tuffaceous } \\
\text { shale, tuffaceous- } \\
\text { sandstone, sand- } \\
\text { stone, and calcare- } \\
\text { ous shale, } \\
\text { greyish-black cal- } \\
\text { careous and silty } \\
\text { shale }\end{array}$ & $\begin{array}{l}\text { middle } \\
\text { Eocene }\end{array}$ & Karaj & $\begin{array}{l}\text { sandstone, } \\
\text { tuff, tuffa- } \\
\text { ceous } \\
\text { shale, } \\
\text { gypsum } \\
\text { shale }\end{array}$ \\
\hline $\begin{array}{l}\text { middle } \\
\text { Paleocene- } \\
\text { early Eo- } \\
\text { cene }\end{array}$ & Chehelkaman & $\begin{array}{l}\text { siliciclastic } \\
\text { and limestone } \\
\text { beds with } \\
\text { evaporate } \\
\text { interbeds, rich } \\
\text { in molluscan } \\
\text { assemblages } \\
\text { specially oys- } \\
\text { ters at the top }\end{array}$ & $\begin{array}{l}\text { early Eo- } \\
\text { cene-middle } \\
\text { Eocene }\end{array}$ & Ziarat & $\begin{array}{l}\text { evaporates } \\
\text { (gypsum), gray to } \\
\text { greenish marl,marly } \\
\text { limestone, and lime- } \\
\text { stone }\end{array}$ & $\begin{array}{l}\text { early } \\
\text { Eocene?- } \\
\text { middle } \\
\text { Eocene }\end{array}$ & Ziarat & $\begin{array}{l}\text { gray marl, } \\
\text { limestone, } \\
\text { silty marl, } \\
\text { marl with } \\
\text { shell beds } \\
\text { (oyster) }\end{array}$ \\
\hline $\begin{array}{l}\text { early Paleo- } \\
\text { cene-middle } \\
\text { Paleocene }\end{array}$ & Pesteligh & $\begin{array}{l}\text { marl, mud- } \\
\text { stone and } \\
\text { siltstone red } \\
\text { bedswith } \\
\text { evaporate } \\
\text { interbeds, } \\
\text { sandstone, and } \\
\text { conglomerates }\end{array}$ & $\begin{array}{l}\text { early Paleo- } \\
\text { cene-early } \\
\text { Eocene }\end{array}$ & Fajan & $\begin{array}{l}\text { conglomerate, red } \\
\text { sandstones, and } \\
\text { sandy marls }\end{array}$ & - & - & - \\
\hline
\end{tabular}

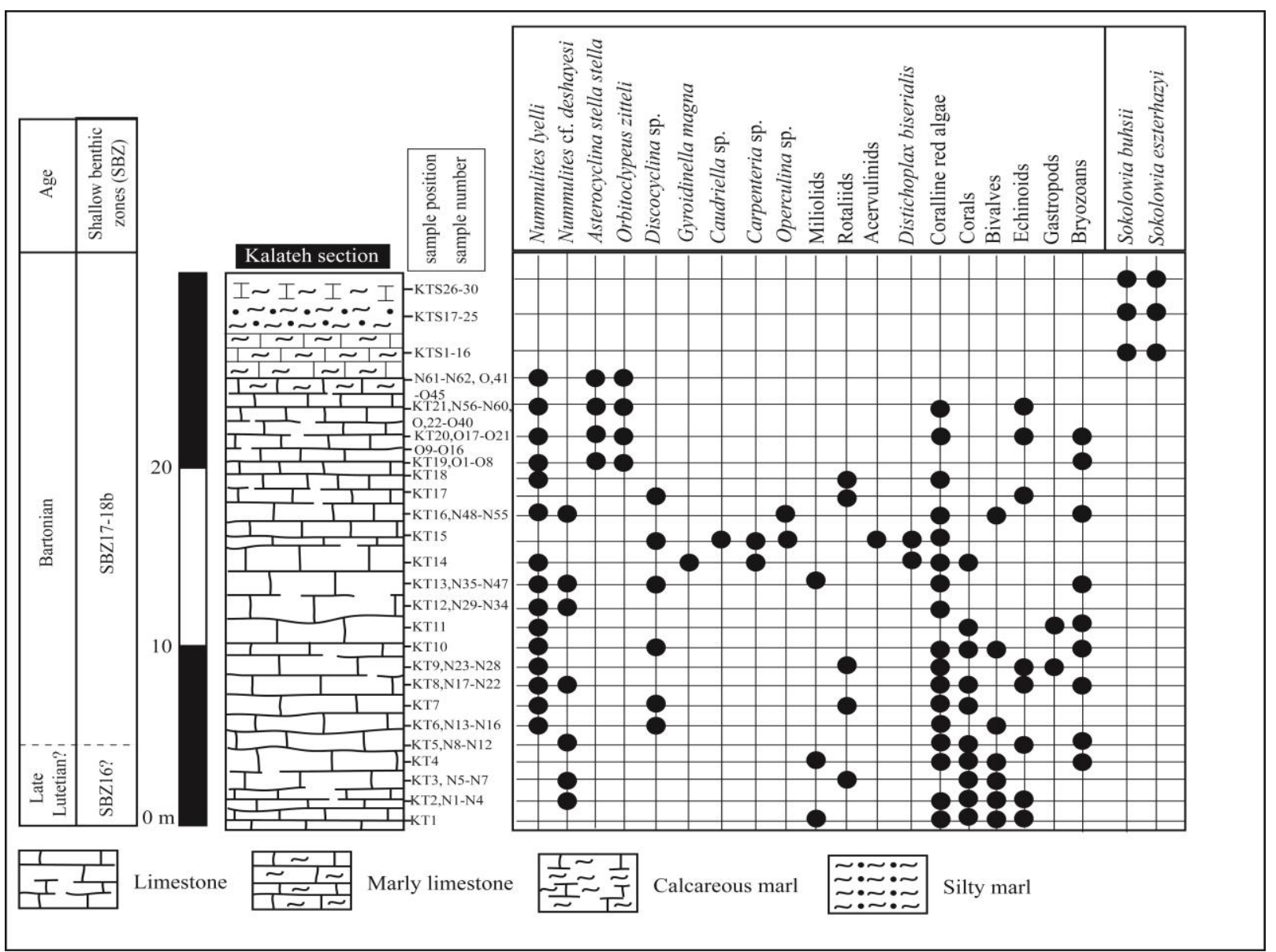

Fig. 2 Stratigraphic distribution of larger foraminiferal species and other fossil groups in the Kalateh section, eastern Alborz zone. Modified after Hadi et al. (2019) 


\section{RESULTS}

\section{Systematic paleontology of Sokolowia from study section}

Class Bivalvia

$\begin{array}{lcc}\text { Suborder } & \text { Ostreina } & \text { Férussac, } \\ \text { Superfamily } & \text { Ostreacea } & \text { Rafinesque, } \\ \text { Family Ostreidae } & \text { Rafinesque, } 1815\end{array}$

Family Ostreidae Rafinesque, 1815

Genus Sokolowia Böhm, 1933

Type species: Gryphaea buhsii Grewingk, 1853

Sokolowia buhsii, Grewingk,

Figure $3 \mathrm{a}-\mathrm{j}$

* 1853 Grypheae buhsii, Grewingk, p. 210, Fig.-t. 1871 Gryphaea esterhazy, Pavay, p. 375, pl. 8, Fig.2; pl. 10, Fig.3.

1937 Gryphaea esterhazy, Vialov, p. 20, pl. XI

1938 Fatina esterhazy, Vialov, p. 16.

1948 Fatina (Sokolowia) esterhazy, Vialov, p. 73, pl. 232.

1970 Fatina (Sokolowia) esterhazyi esterhazyi, Berizzi Quarto di Palo, p. 188, pl. 29, Figs. 1- 2, pl. 30, Fig. 1.

1971 Sokolowia, Stenzel, p. 1147, Figs. J121-J122.

2004 Sokolowia esterhazyi, Rusu et al., p. 451, pl. 1, Figs. $1-2$

2011 Sokolowia buhsii- Salahi \& Vahidinia, p. 56, pl. 1, Fig. 4

2014 Sokolowia buhsii- Bosboom et al., p. 110, Fig. 6. 9. 2016 Sokolowia buhsii- Bougeois et al., p. 613, Fig. 1. iii.

Material: eighteen left valves, twelve right valves, MASSH 0001 - MASSH 0030.

Stratigraphic occurrence in the Alborz Basin: Ziarat Formation, Kalateh Section: Horizon 1 at $26.5 \mathrm{~m}$ from the base; horizon 2 at $27.5 \mathrm{~m}$ from the base; horizon 3 at $29 \mathrm{~m}$ from the base. Dimensions; (left valve): length (L) 54 $\mathrm{mm}$, height (H) $79 \mathrm{~mm}$, shell thickness $46 \mathrm{~mm}$, (right valve): length (L) $32 \mathrm{~mm}$, height (H) $43 \mathrm{~mm}$, shell thickness $11 \mathrm{~mm}$.

Description: Our Sokolowia specimens are characterized by well-preserved, medium to large sized, inflated, subequilateral, thick walled shells, homeomorphous with Gryphaea (gryph shaped). The left valve is strongly convex with a narrow, high and recurved umbo. The ligament area is oblique, the interior shell surface smooth. In the ovoid internal cavity the reniform and semicircular muscle scar is placed near its center. The right valve is inequilateral, flattened, concave and triangular in outline, without ribs, but with fine concentric growth lines. The left valve is covered partially or fully with weak to strong radial ribs; they are slender and densely spaced. In the umbonal region, they are a lot and in short distance, but almost disappear toward ventral margin part and only concentric lamellae can be visible.

Remarks: Ornamentations of the Sokolowia buhsii morph. Buhsii is present in the left valve from the umbonal region up to the ventral margin, whilst in the Sokolowia buhsii morph. Esterhazyi they are limited to the umbonal region, almost disappearing toward the ventral margin where concentric lamellae become prominent (Fig. 3). Note, that also Stenzel (1971) considered latter differences as morphological variation of the same species.

\section{DISCUSSION}

\section{Paleobiology of Sokolowia}

Sokolowia is probably one of the descendants of Turkestrea (Vyalov, 1936; Griffin et al., 2005). It shows a very rapid evolution, short duration and has a provincial paleobiogeographic extent, being restricted to the middlelate Eocene of Central Asia and Romania (Berizzi Quarto di Palo, 1970; Stenzel, 1971; Lan, 1997; Rusu et al., 2004; Bosboom et al., 2011; Salahi \& Vahidinia, 2011). Sokolowia is known as a good environmental proxy from Eocene successions having great importance in the reconstruction of sedimentary environments, especially in relation to paleo-depth, water depth, salinity and substrate (Lan, 1997; Bougeois et al., 2016; Bosboom et al., 2011). From paleoecological perspective, Sokolowia was an epibenthic and suspension feeder, characterized by massive and large-sized shells. It was well adapted to solitary life in the subtidal shallow marine water conditions, with their left valves lying on soft muddy and sandy bottoms, partially sunk into the substratum, whereas their flat right valves attained nearly horizontal position (Stenzel, 1971; Lan, 1997; Rusu et al., 2004; Bosboom et al., 2011). Several authors (e.g. Stenzel, 1971; Lan, 1997; Meszaros et al., 1987) pointed out that Sokolowia lived in normal salinity conditions in a deeper part of the shallow water zone under the influence of wave action. Their thickwalled, heavy shells provided them practically immovable by water turbulence at the sea bottom.

\section{Age of the Sokolowia horizons in NE Iran}

The maximum age of the Sokolowia buhsii and S. eszterhazyi horizon in the Kalateh section is Bartonian. Hadi et al. (2019), established this age for the preceding lithostratigraphic unit in the section bearing larger perforate hyaline foraminifera such as orthophragmines (Orbitoclypeus and Asterocyclina) and nummulitid assemblages (Nummulites) (Fig. 2). Nummulitid accumulations dominated by Nummulites lyelli (Fig. 4a-e) associated with A-forms of Orbitoclypeus zitteli (Fig. 4f-h) and Asterocyclina stella stella (Fig. $4 \mathrm{i}$ ) along with other biogenic components within this interval including small benthic foraminifera (miliolids and rotaliids), larger benthic foraminifera such as $N$. cf. deshayesi, Operculina sp., and encrusting foraminifera (Carpenteria sp. and Gyroidinella magna allow a precise biostratigraphic correlation with the SBZ17-SBZ18b of Serra-Kiel et al. (1998) and Less and Özcan (2012). Because, corresponding foraminifera are missing in the Sokolowia bearing unit in the study section, its upper age limit remains uncertain (Fig. 2).

Still, the "Sokolowia horizon" from the Alborz region can be well compared with such accumulations from the Khangiran Formation in the Kopet-Dagh basin (NE Iran), in which Salahi \& Vahidinia (2011) considered the "Sokolowia horizon" of the Lutetian-Bartonian age. Thus, we assume also for the corresponding horizon of the Kalateh section the Bartonian age.

\section{Correlation of the Sokolowia horizon in adjacent ba-} sins

Sokolowia had extensive paleogeographic distribution throughout the Central Asian Basin System representing 


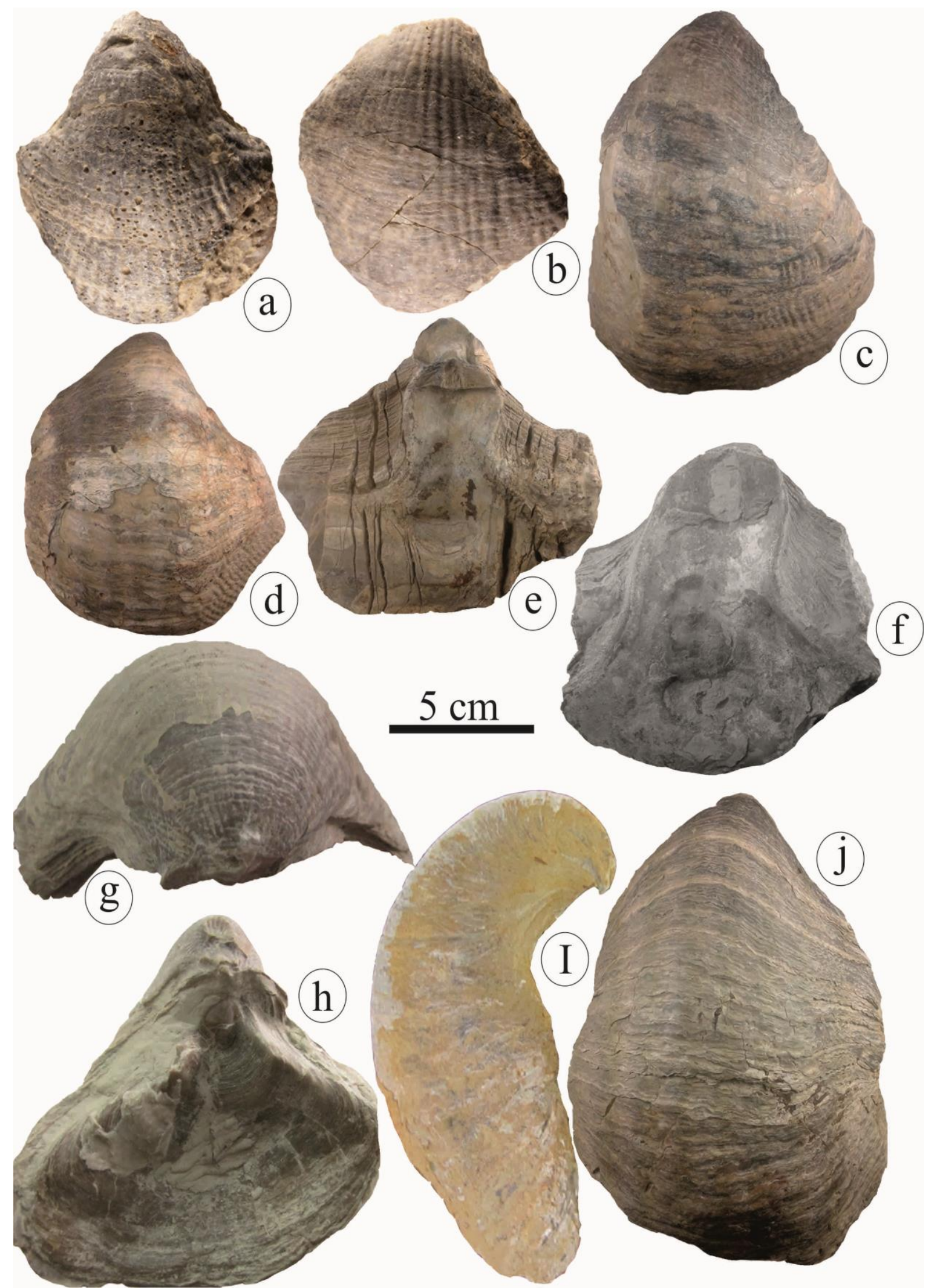

Fig. 3 a-f Sokolowia buhsii morph. Buhsii; g-j Sokolowiabuhsii morph. esterhazyi from Kalateh section (Eastern Alborz region). 


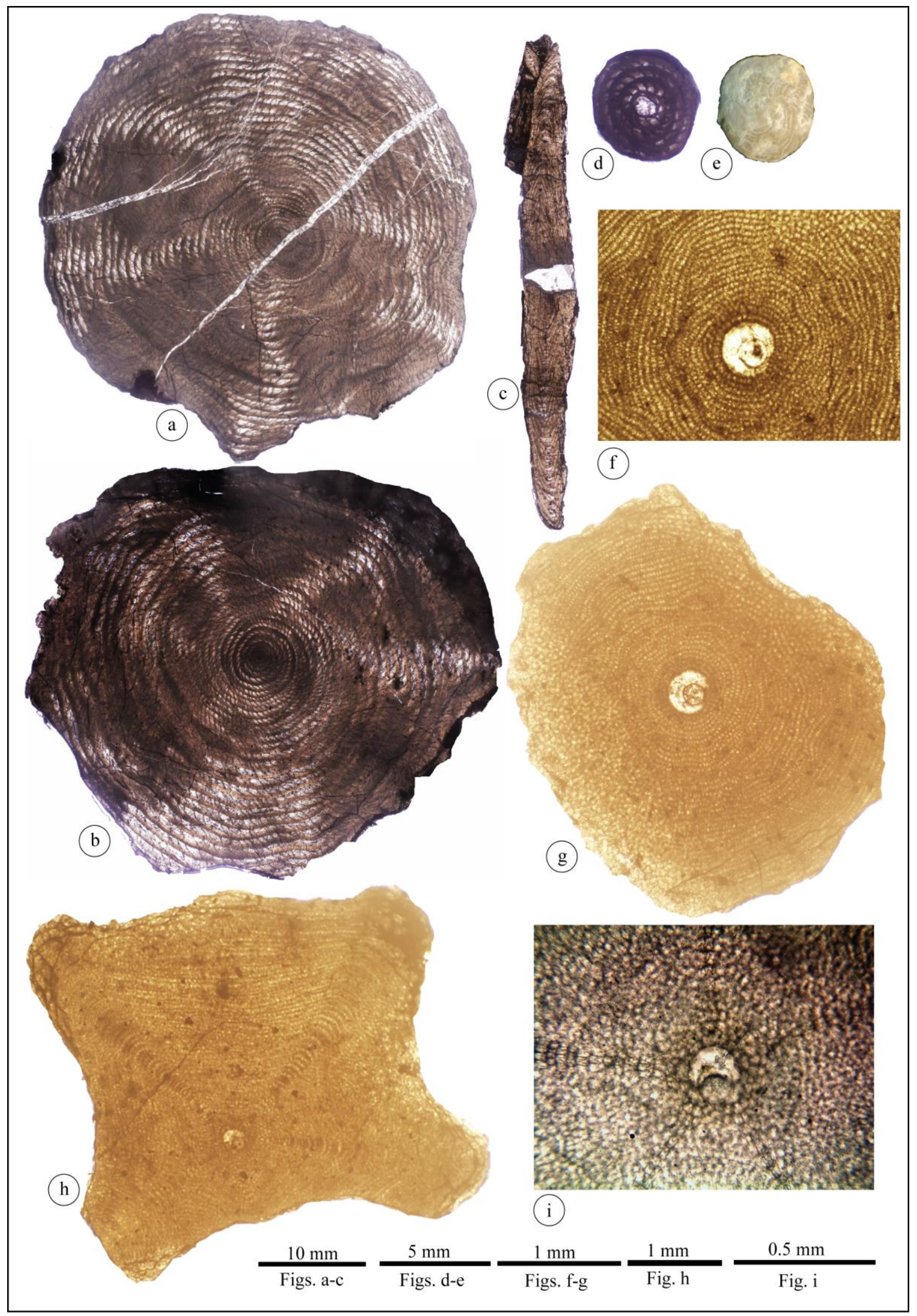

Fig. 4 Biostratigraphically significant larger foraminifera taxa: a-e Equatorial and axial sections of both megalospheric and microspheric form Nummulites lyelli (D'Archiac \& Haime). a-b microspheric form, equatorial section, sample N59N60, c microspheric form, axial section, sample N61, d megalospheric form, equatorial section, sample N55, e external view, f-g Equatorial sections of megalospheric form Orbitoclypeus zitteli (Checchia-Rispoli), sample O25 \& O45, h-i Equatorial sections of megalospheric form Asterocyclina stella stella (Gümbel), sample O32. Modified after Hadi et al. (2019). 


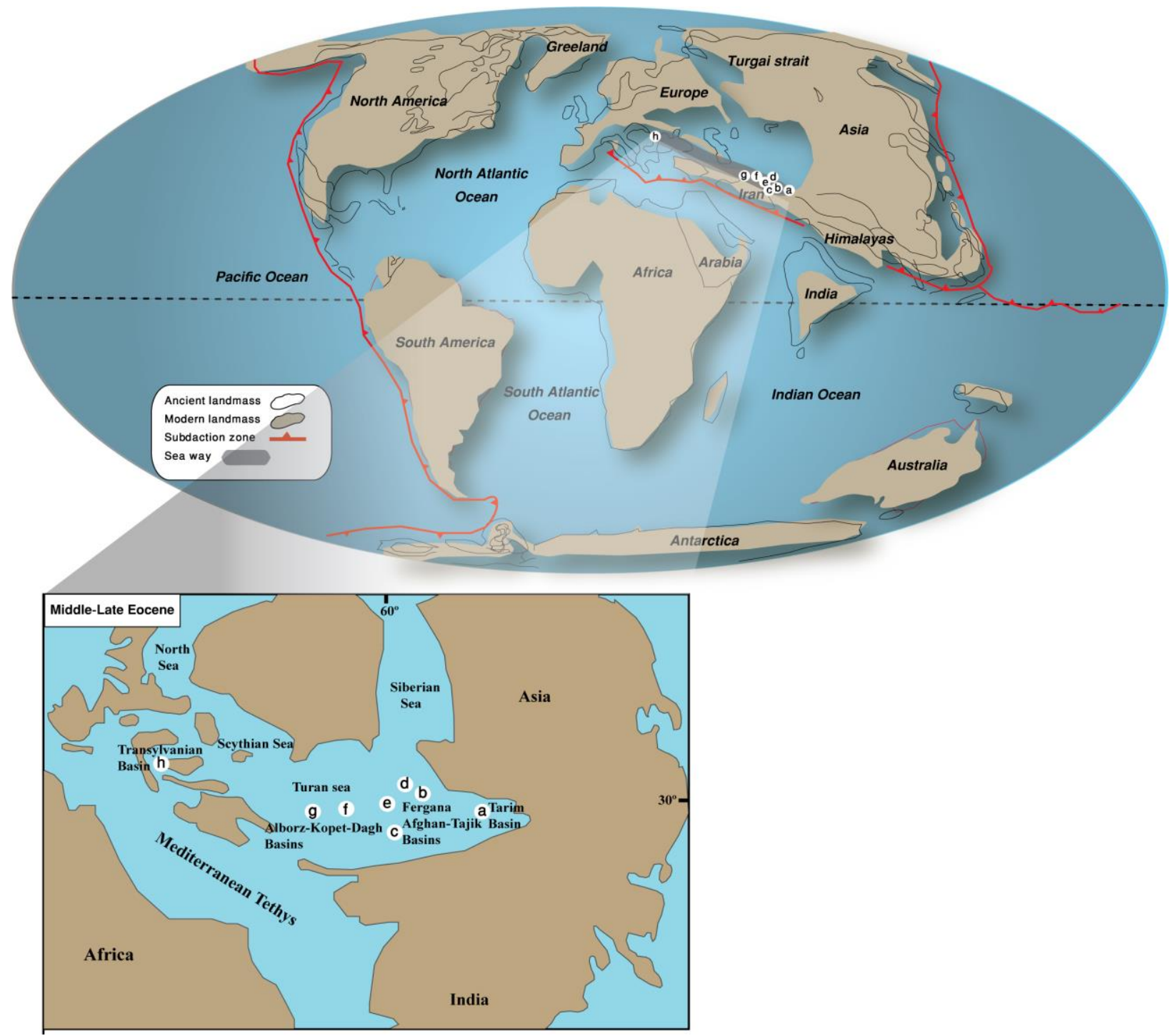

Fig. 5 The palaeogeographic distribution of Sokolowia in the middle Eocene-late Eocene of the Central Asian and Europe (Black Sea area) (modified after Scotese, 2001; Popove et al., 2004; Abels et al., 2011). a Tarim basin (Lan, 1997; Bosboom et al., 011). b Ferghana basin (Vyalov, 1935; Berizzi Quarto di Palo, 1970). c Afghan-Tajik (Vyalov, 1935; Berizzi Quarto di Palo, 1970). d Syr Darya (Romanovsky, 1880; Gorizdro, 1913). e Amu Darya (Vyalov, 1935; Berizzi Quarto di Palo, 1970). f Kopet-Dagh (Salahi \& Vahidinia, 2011). g Alborz (Grewingk, 1853; present study). (h) Transylvanian (Rusu et al., 2004).

the eastern and central part of the proto-Para Tethys epicontinental sea during the middle to late Eocene timespan (Bosboom et al., 2015). Therefore, they can be considered as stratigraphic index fossils diagnostic for that interval. Besides, Sokolowia has always been considered as an important macrofossil for determining the age of formations in central Asian marine deposits (e.g., Vialov, 1937, 1948; Osipova, 1958; Lan, 1997).

The presence of the Sokolowia accumulations in the Ferghana basin in the eastern of Uzbekistan, the Amu-Darya basin of Turkmenistan and Uzbekistan as well as the northwest of Afghanistan demonstrates a widespread dispersal in central Asian basins during the late Lutetian to the early Priabonian (e.g. Berizzi Quarto di Palo, 1970; Ulmishek, 2004). Further east, in the Tarim Basin (NW China) the "Sokolowia horizon" was also reported from the late Lutetian to early Priabonian Kalatar Formation by Bosboom et al. (2011, 2015) and Bougeois et al. (2016). Therefore, the Eocene deposits containing Sokolowia in the Central Asian region, including the Kopet-Dagh,
Amu-Darya, Syr-Darya, Afghan-Tajik, Ferghana, Tarim and Alborz basins comprise the late Lutetian-early Priabonian time-interval.

Conspicuously, this prominent Central Asian key-horizon is known from Europe only in the Transylvanain Basin of western Romania (Rusu et al., 2004). There, the Sokolowia eszterhazyi horizon is situated below the Nummulites perforatus accumulations indicating the late Lutetian-early Bartonian age. It belongs to the Capuşu Formation, attributed to the late Lutetian-early Bartonian biozones P12 (planktonic foraminifera) and NP16 (calcareous nannoplankton) (Rusu et al, 2004; Gradstein et al., 2004). In this unit, Odin (1978) reported the age of $41.2 \pm 2.1 \mathrm{Ma}$ for Sokolowia eszterhazyi beds by radiometric date (K/Ar analyses).

The aforementioned reports show the "Sokolowia horizon" as a valuable marker bed, which can be well used for the correlation of adjacent basins in the vast region from the easternmost central Asia (China) to the southeastern Europe (Romania) (Berizzi Quarto di Palo, 1970; 


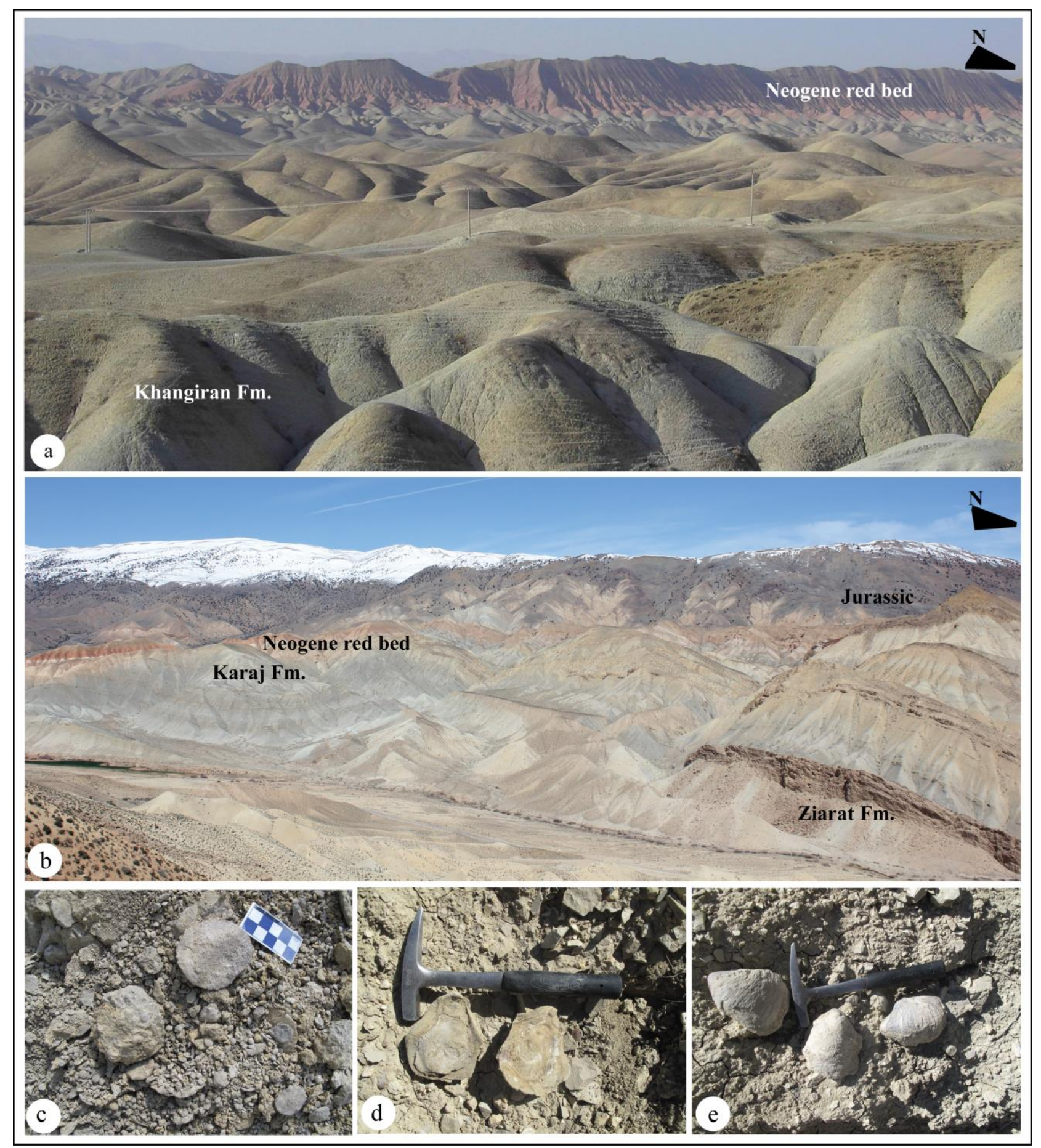

Fig. 6 a Outcrop view of the Khangiran Formation and Neogene red beds in the Yaghol section (Kopet-Dagh region). b Panoramic view of the Ziarat Formation, Karaj Formation and Neogene red beds in the Kalateh section (Alborz region). c Close-up view of the Nummulites tests in the Kalateh section. d-e Sokolowia samples of the calcareous marl deposits in the Kalateh section.

Dzhalilov et al., 1982; Lan, 1997; Rusu et al., 2004; Bosboom et al., 2011; Salahi \& Vahidinia, 2011). Such a distribution can only be explained by a seaway connecting easternmost Central Asia with the Transylvanian Basin (Fig. 5). Already, Burtman (2000) and Popov et al. (2004) referred to the Eocene Tarim Basin (China) as the easternmost part of a huge Eurasian sea extending throughout the Ferghana, Afghan-Tajik, Syr-Darya, Amu-Darya and Kopet-Dagh basins, into the Alborz basin of NE Iran (Fig. 5). This vast epicontinental sea belonging to the Tethys domain gave rise in the Oligocene to the Paratethys Sea (see Royal, 1999; Popov et al., 2004; Dercourt et al., 1993; Bosboom et al., 2014; Tang et al., 1992; Burtman \& Molnar, 1993; Bosboom et al., 2015).

\section{Lithostratigraphic comparison of Paleogene succes-} sions in central Asian basins

The lithostratigraphic studies of the Kalateh section pertains a regional scale comparison of the Ziarat Formation in the eastern Alborz region with other parts of Alborz (Central-Western Alborz) (e.g. see Khatibi-Mehr and 

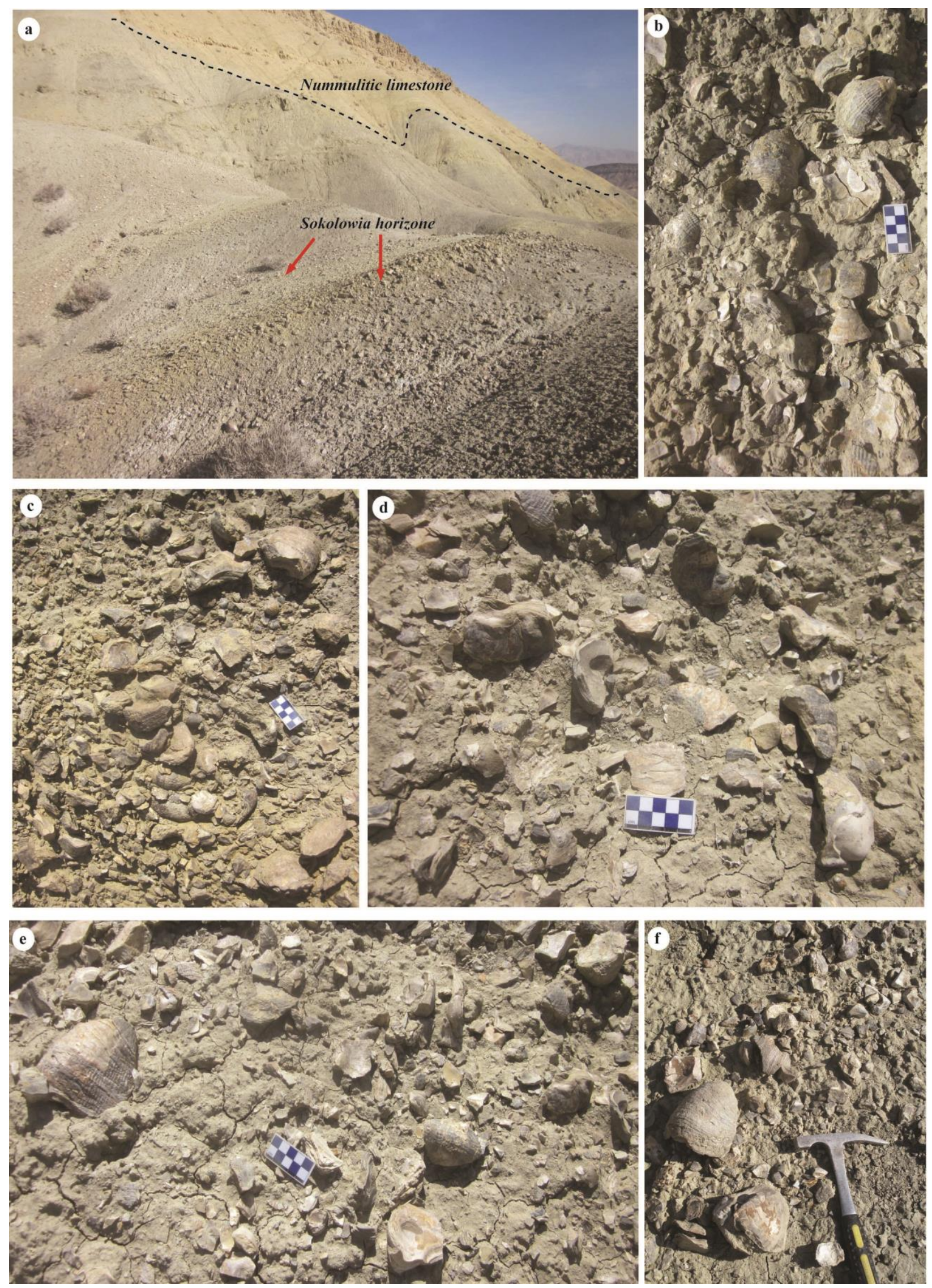

Fig. 7 a Field photographs of the "Sokolowia horizon" form the Ziarat Formation, Kalateh section (Alborz region). b-c Close-up view of densely packed of oyster concentrations and $\mathbf{d - f}$ shells commonly show sparse distribution. 


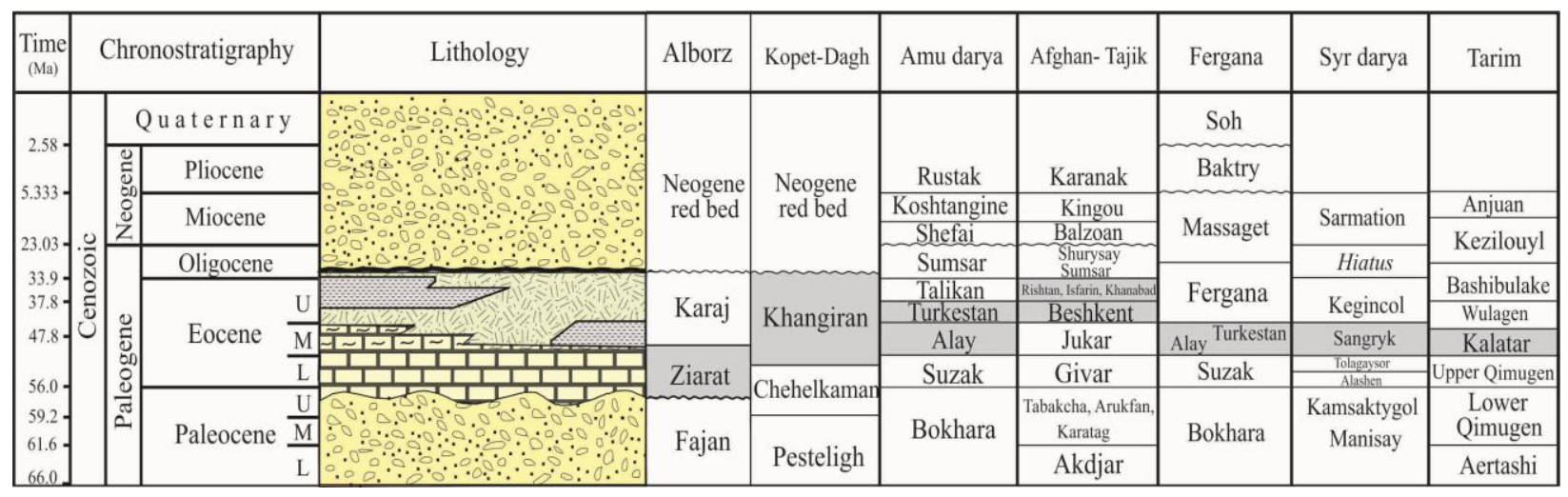

Fig. 8 Stratigraphic chart of Paleogene formations in different Central Asian basins, including Alborz (Aghanabati, 2004), KopetDagh (Afshar-Harb, 1994), Amu Darya (Ulmishek, 2004), Afghan-Tajik (Ulmishek, 2004), Ferghana (Bande et al., 2015), Syr darya (King et al., 2013) and Tarim (Yang et al., 2013). Highlights on the stratigraphic chart show the presence of the Sokolowia horizon in the basins of Kopet-Dagh (Salahi \& Vahidinia, 2011), Amu darya (Berizzi Quarto di Palo, 1970), Afghan- Tajik (Berizzi Quarto di Palo, 1970), Ferghana (Vyalov, 1935), Syr darya (Romanovski, 1880; Gorizdro, 1913), Tarim (Lan, 1997; Bosboom et al., 2011) and Alborz (present study).

Adabi, 2014; Hadi et al., 2016). Furthermore, they indicate relationship with the sequences of Khangiran Formation in the Kopet-Dagh region in the northnortheastern Iran during the early Paleogene (Figs. 6-7).

At a larger scale, the Paleogene deposition in Central Asian basins often started with red continental clastics in the early Paleocene, such as Fajan Formation in Alborz, Pesteligh Formation in Kopet-Dagh and Bokhara Formation in the Amu-Darya. Red beds are also present in the some parts of Aertashi Formation in Tarim Basin (Bosboom et al., 2015) (Fig. 8). The late Paleocene sediments continue mainly with shallow carbonate deposits, as well as terrigenous rocks and anhydrite (partly Ziarat Formation in Alborz, Chehelkaman Formation in KopetDagh, Suzak Formation in Amu-Darya and Lower Qimugen Formation in Tarim). At the beginning of the Eocene, the deposition continues by limestone, marly limestone and rarely silty marl in Ziarat Formation, and afterward starts with siliciclastics, such as shale, siltstone, sandstone or even silty marl, and in some places also by volcanic deposits (green tuffs). Corresponding sediments are present in Karaj Formation in Alborz, Khangiran Formation in Kopet-Dagh, Alay and Turkestan Formation in Amu-Darya, and Upper Qimugen and Kalatar Formation in Tarim) (Fig. 8; e.g., see Otto, 1997; King et al., 2013; Bosboom et al., 2014; Bougeois et al., 2016). Finally, the Oligocene deposits are often represented by red continental clastics that are in most cases discontinuously located on Eocene marine deposits. They include Sumsar Formation in the former Soviet Union, Kezilouyl Formation in the Tarim Basin of China, and Lower Red Formation in the Kopet-Dagh and Alborz Basins of Iran (e.g., see Egamberdyev \& Mayvandi, 1992; Bosboom et al, 2014; Bougeois et al. 2016).

These lithostratigraphical features and macro-benthic data similarities show related paleoenvironmental histories of the Alborz, Kopet-Dagh, and the adjacent basins of Central Asian regions during the Paleogene time. On the other hand, the paleogeography, controlling mechanisms (e.g. eustasy and tectonism) and paleoenvironmental impacts of the proto-Paratethys sea in the easternmost parts from Central Asia are studied in details (see Royal, 1999;
Popov et al., 2004; Bosboom et al., 2014; Bosboom et al., 2015), while the aforementioned data has not been yet properly examined in Iran.The names of known formations of Paleogene sequences in the mentioned areas are shown in Fig. 8.

\section{CONCLUSION}

During the middle Eocene, the Eastern Alborz region as apart of the Alpine-Himalayan orogenic system on the southern margin of the Caspian Sea was covered by shallow-marine deposits bearing high abundance larger foraminifera along with oyster bivalves. The present study provides a new insight into the Eocene sequences of the eastern Alborz region by the following results:

1- The studied oyster bivalves Sokolowia buhsii morph. buhsii and S. buhsii morph. eszterhazyi from the Ziarat Formation in the eastern Alborz region, found on top of larger benthic foraminifera accumulations with Nиттиlites lyelli, Orbitoclypeus zitteli and Asterocyclina stella stella, are most likely Bartonian in age.

2- The presence of Sokolowia key horizon in NE Iran at the crossroads between Central Asia and Southeastern Europe suggests a well-established seaway along the southern margin of a large-sized Eurasian epicontinental sea during middle-late Eocene (late Lutetian-early Priabonian).

3- Correlation of the middle Paleogene sedimentary sequence of eastern Alborz basin with different sedimentary basins in vast areas of Central Asia strikes out similarities in their tectono-stratigraphic architecture, suggesting a related geodynamic and paleoenvironmental history shaped apparently by the Alpine-Himalayan orogenic system.

\section{ACKNOWLEDGMENTS}

We are grateful to Oleg Mandic and to anonymous reviewer for their corrections, comments and suggestions that strongly improved the original manuscript. 


\section{REFERENCES}

Abels, H.A., Dupont-Nivet, G., Xiao, G., Bosboom, R.E. \& Krijgsman, W., 2011. Step-wise Asian paleoenvironmental changes preceding the Eocene-Oligocene transition (EOT) in the terrestrial Xining Basin, China.Palaeogeography, Palaeoclimatology, Palaeoecology, 299: 399-412.

Afshar-Harb, A., 1994.Geology of Kopet Dagh. In: Hushmandzadeh, A., (ed.) Treatise on the Geology of Iran, Geological Survey of Iran, Tehran, pp.1-275.

Aghanabati, A., 2004. Geology of Iran. Geological Survey of Iran, $587 \mathrm{pp}$.

Alavi, M., 1996. Tectonostratigraphic synthesis and structural style of the Alborz mountain system in northern Iran. Geodynamics, 21 (1): 1-33.

Asiabanha, A. \& Foden, J., 2012. Post-collisional transition from an extensional volcano-sedimentary basin to a continental arc in the Alborz Ranges, N-Iran. Lithos, 148: 98-111.

Berizzi Quarto di Palo, A., 1970. Paleogene pelecypods from Kataghan and Badakhshan (North-East Afganistan). In: Desio, A. (ed.) Fossils of North-East Afganistan: Italian Expeditions to the Karakorum (K2), and Hindu Kush, Brill, Leiden, IV/2, pp.161-240.

Böhm, J., 1933. "Die palaeogene Fauna OstTurkestans." Zeitschrift der Deutschen geologischen Gesellschaft, 85: 99-118.

Bosboom, R.E., Dupont-Nivet, G., Houben, A.J.P., Brinkhuis, H., Villa, G., Mandic, O., Stoica, M., Zachariasse, W.J., Guo, Z. \&Li, C., 2011. Late Eocene Sea Retreat from the Tarim Basin (West China) and Concomitant Asian Paleoenvironmental Change. Palaeogeography, Palaeoclimatology, Palaeoecology, 299: 385-398.

Bosboom, R., Dupont-Nivet, G., Grothe, A., Brinkhuis, H., Villa, G., Mandic, O., Stoica, M., Huang, W., Yang, W., Guo, Z. \& Krijgsman, W., 2014. Linking Tarim Basin sea retreat (west China) and Asian aridification in the late Eocene. Basin Research, 26 (5): 621-640.

Bosboom, R., Mandic, O., Dupont-Nivet, G., Proust, J. \&Ormukov, C., 2015. Late Eocene paleogeography of the Proto-Paratethys Sea in Central Asia (NW China, S Kyrgyzstan and SW Tajikistan). Geological Society of London, Special Publications, 427 (1): 565-588.

Bougeois, L., De Rafelis, M., Reichart, G.J., De Nooijert, L. \& Dupont-Nivet, G., 2016. Mg/Ca in fossil oyster shells as palaeo temperature proxy, an example from the Palaeogene of Central Asia. Palaeogeography, Palaeoclimatology, Palaeoecology, 441 (4): 611-626.

Bugrova, E.M., 2009. Paleogen Turkmenistana (Obnovlenaja shema zonaljnogo raschlenenija i korrelacii). Neftegasovaa geologia. Teoriaipractika, 4: 1-32.

Burtman, V.S. \& Molnar, P., 1993. Geological and geophysical evidence for deep subduction of continental crust beneath the Pamir. Geological Society of America, Special Publications, 281: 1-76.

Burtman, V.S., 2000.Cenozoic crustal shortening between the Pamir and Tien Shan and a reconstruction of the Pamir-Tien Shan transition zone for the Cretaceous and Palaeogene.Tectonophysics, 319: 69-92.
Cita, M.B. \& Premoli Silva, I., 1975. Micropaleontological notes on some Cretaceous-Eocene sections in North-Eastern Afghanistan. In: Desio, A. (ed.) Geology of Central Badakhshan: Italian Expeditions to the Karakorum (K2), and Hindu Kush. Brill, Leiden, pp. 457-494.

Dellenbach, J., 1964. Contribution et l'etudegeologique de la regionsituee a l'est du Tehran (Iran). PhD, Faculté des Science de l'Universite, Strasbourg (France), $117 \mathrm{pp}$.

Desio, A. \& Martina, E., 1975. Some stratigraphical sequences of Katagan and surrounding regions.In: Desio, A. (ed.) Geology of Central Badakhshan: Italian Expeditions to the Karakorum (K2), and Hindu Kush. Brill, Leiden.

Dercourt, J., Ricou, L.E. \& Vrielynck, B., 1993. Atlas Tethys Paleoenvironmental Maps. Commision for the Geological Map of the World, Paris.

Dzhalilov, M.R., Alekseev, M.N., Andreev, Y.N. \& Salibaev, G.K., 1982. Mesozoic and Cenozoic Deposits of the Northern Part of the Afghano-Tajik Basin.Mineral resources developent series, $131 \mathrm{pp}$.

Egamberdyev, M. \& Mayvandi, M., 1992. Main geologic and geochemical factors affecting petroleum potential of southern Uzbekistan and northern Afghanistan. Uzbekskiy Geologicheskiy Zhurnal, 3 (4): 55-65.

Férussac, A.E., de, 1822. Tableaux systematiques des animaux ollusques: Paris, A. Bertrand; London, J.B. Sowerby, $111 \mathrm{pp}$

Gradstein, J., Ogg, G. \& Smith, G.A., 2004. A Geologic Time Scale. Cambridge University Press, 589 pp.

Grewingk, C., 1853. Die Geognostischen Und Orographischen Verhaeltnisse Des Noerdlichen Persiens. In: Verhandlungen Der R.K Mineralogischen Gesellschaft (ed.) 1852-1853, St. Petersburg. pp. 97-245.

Griffin, M., Casadio, S. \& Parras, A., 2005. Maastrichtian and Danian species of Turkostreini (Ostreidae, Crassostreinae) from the Neuquén Basin, Argentina. Paleontology, 42 (2): 257-276.

Gorizdro, S.F., 1913. Material for the Tertiary Turkestan fauna study: Trudy Imperatorskago SanktPeterburgskagoObshchestvaEstestvoispytateley.Otdeleniegeologii i mineralogii, 37 (5): 1-57.

Hadi, M., Mosaddegh, H., Abbassi, N., 2016. Microfacies and biofabric of nummulite accumulations (Bank) from the Eocene deposits of Western Alborz (NW Iran). Journal of AfricanEarth Sciences, 124: 216-233.

Hadi, M., Less, G. \& Vahidinia, M. (2019): Eocene larger benthic foraminifera (alveolinids, nummulitids, and orthophragmines) from the eastern Alborzregion (NE Iran): taxonomy and biostratigraphy implications. Revue de Micropaléontologie. doi.org/10.1016/j.revmic.2019.01.001

Mehr, M.K. \& Adabi, M. H., 2014. Microfacies and geochemical evidence for original aragonite mineralogy of a foraminifera-dominated carbonate ramp system in the late Paleocene to Middle Eocene, Alborz basin, Iran. Carbonates and Evaporites, 29 (2): 155-175.

King, C., Iakovleva, A.I., Steurbaut, E., HeilmannClausen, C. \& Ward, D.J., 2013. The Aktulagay section, west Kazakhstan: a key site for Early Eocene 
northern mid-latitude stratigraphy. Stratigraphy, 10: 171-209.

Lan, X., 1997. Paleogene bivalve communities in the western Tarim basin and their paleoenvironmental implications. Paleoworld, 7: 137-157.

Lan, X. \& Wei, J., 1995.Late Cretaceous-Early Tertiary marine bivalve fauna from the western Tarim basin. Chinese Science Publishing House, Beijing, 212 pp.

Less, G., Özcan, E., 2012. Bartonian-Priabonian larger benthic foraminiferal events in the western Tethys. Austrian Journal of Earth Sciences, 105 (1): 129-140.

Mészáros, N., Moga, V. \& Ianoliu, C., 1987. Studying the various groups of fossil organisms of Leghia-Leghia Băi. In: The Eocene from the Transylvanian Basin, Cluj-Napoca, 143-150.

Odin, G.S., 1978. Isotopic dates for a Paleogene Time Scale. American Association of Petroleum Geologists (AAPG), Studies in Geology, 6: 247-257.

Okay, A. I., 1989. Alpine-Himalayan blueschists. Annual Review of Earth and Planetary Sciences 17: 55-87.

Osipova, A.I., 1958. Polemical questions concerning Lower Paleogene stratigraphy in Southeastern Central Asia. Nauk USSR, Geology, 8: 75-89.

Otto, S.C., 1997. Mesozoic-Cenozoic history of deformation and petroleum systems in sedimentary basins of Central Asia; implications of collisions on the Eurasian margin. Petroleum Geoscience, 3: 327-341.

Özcan, E., Hanif, M., Ali, N. \& Yücel, A.O., 2015. Early Eocene orthophragminids (Foraminifera) from the type-locality of Discocyclina ranikotensis Davies, 1927, Thal, NW Himalayas, Pakistan: insights into the orthophragminid palaeobiogeography. Geodinamica Acta 27: 267-299.

Pavay, E. 1871. Kolozsvar környekenek földtani viszonyai. A Magyar Kiralyi Földtani Intezet Evkönyve, 1: 327-462.

Popov, S., Rögl, F., Rozanov, A.Y., Steininger, F.F., Shcherba, I.G. \& Kovac, M., 2004. Lithological Paleogeographic Maps of Paratethys 10 Maps Late Eocene to Pliocene. Courier Forschungsinstitut Senckenberg, 250: 1-42.

PremoliSilva, I., 1970. Cretaceous-Eocene microfaunas from Western Badakhshan and Kataghan (North-East Afganistan). In: Desio, A. (ed.) Fossils of North-East Afganistan: Italian Expeditions to the Karakorum (K2), and Hindu Kush. Brill, Leiden, pp. 119-160.

Rafinesque, C.S., 1815. Analyse de la nature, ou tableau de l'univers et des corps organisés. Palerme, $224 \mathrm{pp}$.

Rezaeian M., 2008. Coupled tectonics, erosion and climate in the Alborz Mountains, Iran. PhD thesis, University of Cambridge, $219 \mathrm{pp}$.

Romanovskiy, G., 1880. Materialienzur Geologie von Turkestan. 1. Lieferung. Geologische und Paläontologische Uebersicht des Nordwestlichen Thian-Schan und des Südöstlichen Theiles der Niederung von Turan. Acad. Wissenschaften, St. Petersburg, $143 \mathrm{pp}$.

Rossi Ronchetti, C., 1975. Megafossils of some localities of North-Eastern Afghanistan. In: Desio, A. (ed.) Geology of Central Badakhshan. Italian Expeditions to the Karakorum (K2), and Hindu Kush. Brill, Leiden, pp. 509-520.
Rusu, A., Brotea, D. \& Melinte, M.C., 2004. Biostratigraphy of the Bartonian deposits from Gilău area (NW Transylvania, Romania). Acta Palaeontologica Romaniae, 4: 441-454.

Salahi, A. \& Vahidinia, M., 2011. Systematic description, paleoecology and pleobiogeography of Khangiran Formation's oysters in the Chehelkaman synclinal section, east of Kopet-dagh. Sedimentary Facies, 4 (1): 54-63.

Salahi, A., Ghaderi, A., Ashouri, A., \& Siabeghodsi, A., In Press. Stratigraphical correlation of Paleogene deposits of the Kopet-Dagh- Central Asia based on lithological and Oyster fauna evidences. Geoscience Journal.

Scotese, C. R., 2001. Atlas of Earth History, vol. 1, p. 52. Paleogeography, Paleomap Project, Arlington, Texas.

Şengör, A.M.C., Altıner, D., Cin, A., Ustaömer, T. \& Hsü, K., 1988. Origin and assembly of the Tethyside orogenic collage at the expense of Gondwana Land. Geological Society, London, Special publications, 37: 119-181.

Serra-Kiel, J., Hottinger, L., Caus, E., Drobne, K., Ferrandez, C., Jauhri, A.K., Less, G., Pavlovec, R., Pignatti, J. \& Samso, J.M., 1998. Larger foraminiferal biostratigraphy of the Tethyan Paleocene and Eocene. Bulletin de la Société géologique de France, 169: 281299.

Sharabi, M., 1990. Geological Map of Iran. 1:250,000 Series, Gorgan. Geological survey of Iran, Tehran.

Stampfli, G., Marcoux, J. \& Baud, A., 1991. Tethyan margins in space and time. Palaeogeography, Palaeoclimatology, Palaeoecology, 87(1-4): 373-409.

Stenzel, H.B., 1971. Oysters. In: Moore, R.C. (ed.) Treatise on Invertebrate Paleontology, Volume 3. Geological Society of America/University of Kansas Press, Boulder, CO /Lawrence, KS, pp. 953-1224.

Stöcklin, J. 1968. Structural history and tectonics of Iran: A review. American Association of Petroleum Geologists (AAPG), 52: 1229-1258.

Stöcklin, J., 1972. Iran Central, septentrional et oriental. Lexique Stratigraphique International. III, Fascicule 9b, Iran. Centre National de la Recherche Scientifique, Paris, $283 \mathrm{pp}$.

Tang, T., Xue, Y. \&Yu, C., 1992. Characteristics and Sedimentary Environments of the Late Cretaceous to Early Tertiary Marine Strata in the Western Tarim, China. Science Press, Beijing, 138 pp.

Thomas, E., 2003. Extinction and food at the sea floor: a high-resolution benthic foraminiferal record across the Initial Eocene Thermal Maximum, Southern Ocean Site 690. In: Wing, S., Gingerich, P., Schmitz, B. \& Thomas, E. (Eds.) Causes and Consequences of Globally Warm Climates of the Paleogene. GSA Special Paper, 369: 319-332.

Ulmishek, G.F., 2004. Petroleum geology and resources of the Amu-Darya Basin, Turkmenistan, Uzbekistan, Afghanistan, and Iran.U.S.Geological Survey Bulletin, 32 pp.

Vyalov, O.S., 1936. Sur la classification des huîtres. Comptes rendus (Doklady) of the Academy of Sciences of the USSR, new series 4 (13), $\mathrm{n}^{\mathrm{o}}$ 1(105): 1720. 
Vialov, O.S., 1937. Sur la clasification des ostreides et leur valeur stratigraphique, International Congress Zoology. Lisbonne, 1627-1638.

Vialov, O.S., 1938. On the Middle-Asiatic Fatina Vialov and Turkostrea Vialov. Izvestija Akademii Nauk SSSR, Moscow.

Vialov, O.S., 1948. Paleogenovie Ustrici Tadzhikskoi Depressii (Paleogene Ostreids from Tajik Depression). Trudy VNIGRI, Leningrad.
Zachos, J.C., Wara, M.W., Bohaty, S.M., Delaney, M.L., Rose-Petrizzo, M., Brill, A., Bralower, T.J. \& Premoli-Silva, I., 2003.A transient rise in tropical sea surface temperature during the Paleocene-Eocene Thermal Maximum. I. Science, 302: 1551-1554. 